\title{
Role of IL-33 in inflammation and disease
}

\author{
Ashley M Miller
}

\begin{abstract}
Interleukin (IL)-33 is a new member of the IL-1 superfamily of cytokines that is expressed by mainly stromal cells, such as epithelial and endothelial cells, and its expression is upregulated following pro-inflammatory stimulation. IL33 can function both as a traditional cytokine and as a nuclear factor regulating gene transcription. It is thought to function as an 'alarmin' released following cell necrosis to alerting the immune system to tissue damage or stress. It mediates its biological effects via interaction with the receptors ST2 (IL-1RL1) and IL-1 receptor accessory protein (IL-1RACP), both of which are widely expressed, particularly by innate immune cells and T helper 2 (Th2) cells. IL-33 strongly induces Th2 cytokine production from these cells and can promote the pathogenesis of Th2-related disease such as asthma, atopic dermatitis and anaphylaxis. However, IL-33 has shown various protective effects in cardiovascular diseases such as atherosclerosis, obesity, type 2 diabetes and cardiac remodeling. Thus, the effects of IL-33 are either pro- or anti-inflammatory depending on the disease and the model. In this review the role of IL-33 in the inflammation of several disease pathologies will be discussed, with particular emphasis on recent advances.
\end{abstract}

\section{Review}

\section{Basic Biology of IL-33}

Interleukin (IL)-33 (also known as IL-1F11) was originally identified as DVS27, a gene up-regulated in canine cerebral vasospasm [1], and as "nuclear factor from high endothelial venules" (NF-HEV) [2]. However, in 2005 analysis of computational structural databases revealed that this protein had close amino acid homology to IL-18, and a $\beta$-sheet trefoil fold structure characteristic of IL-1 family members [3]. IL-33 binds to a ST2L (also known as T1, IL-1RL1, DER4), which is a member of the Toll-like receptor (TLR)/IL1R superfamily. IL-33/ ST2L then forms a complex with the ubiquitously expressed IL-1R accessory protein (IL-1RAcP) [4-6]. Signaling is induced through the cytoplasmic Toll-interleukin-1 receptor (TIR) domain of IL-1RAcP. This leads to recruitment of the adaptor protein MyD88 and activation of transcription factors such as NF- $\kappa$ B via TRAF6, IRAK-1/4 and MAP kinases and the production of inflammatory mediators (Figure 1) [3]. The ST2 gene can also encode at least 2 other isoforms in addition to ST2L by alternative splicing, including a secreted soluble ST2 (sST2) form which can serve as a decoy receptor for IL-33 [7], and an ST2V variant form present mainly

\footnotetext{
Correspondence: Ashley.Miller@glasgow.ac.uk

Institute of Infection, Immunity and Inflammation, College of Medical,

Veterinary and Life Sciences, GBRC, University of Glasgow, Glasgow G12 8TA, UK
}

(c) 2011 Miller; licensee BioMed Central Ltd. This is an Open Access article distributed under the terms of the Creative Commons Attribution License (http://creativecommons.org/licenses/by/2.0), which permits unrestricted use, distribution, and reproduction in in the gut of humans [8]. Signaling through ST2L also appears to be negatively regulated by the molecule single Ig IL-1R-related molecule (SIGIRR) and IL-33 induced immune responses were enhanced in SIGIRR ${ }^{-/-}$ mice [9].

IL-33 appears to be a cytokine with dual function, acting both as a traditional cytokine through activation of the ST2L receptor complex and as an intracellular nuclear factor with transcriptional regulatory properties [10]. The amino terminus of the IL-33 molecule contains a nuclear localization signal and a homeodomain (helix-turn-helix-like motif) that can bind to heterochromatin in the nucleus and has similar structure to the Drosophila transcription factor engrailed $[2,11]$. In a similar manner to which a motif found in Kaposi sarcoma herpesvirus LANA (latency-associated nuclear antigen) attaches its viral genomes to mitotic chromosomes, nuclear IL-33 is thought to be involved in transcriptional repression by binding to the $\mathrm{H} 2 \mathrm{~A}-\mathrm{H} 2 \mathrm{~B}$ acidic pocket of nucleosomes and regulating chromatin compaction by promoting nucleosome-nucleosome interactions [12]. However, the specific transcriptional targets or the biological effects of nuclear IL-33 are unclear at present.

Both IL-1 $\beta$ and IL-18 are synthesized as a biologically inactive precursors and activated by caspase- 1 cleavage under pro-inflammatory conditions and it was initially thought that IL-33 underwent similar processing by any medium, provided the original work is properly cited.

C Biomed Central 


\section{$\underline{\text { Necrosis }}$}

\section{Damage Stromal cells}

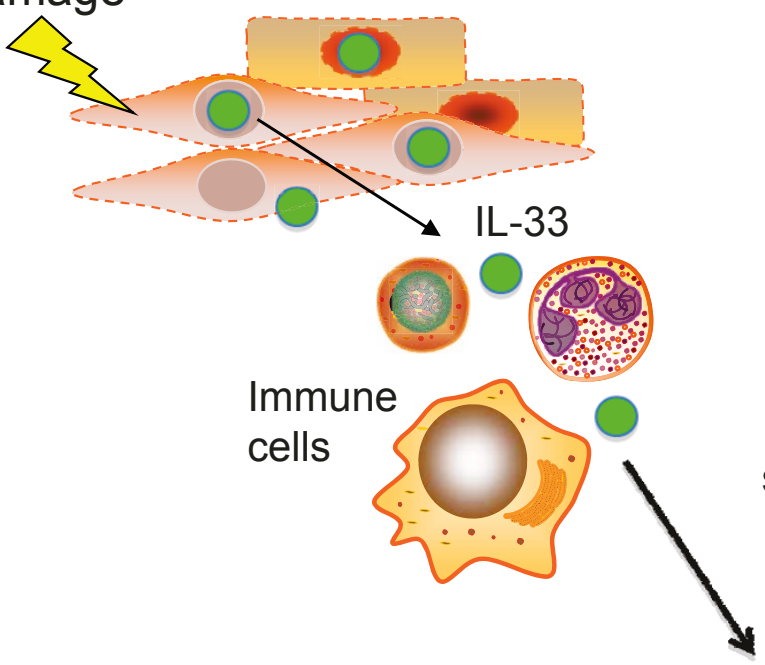

\section{Apoptosis}

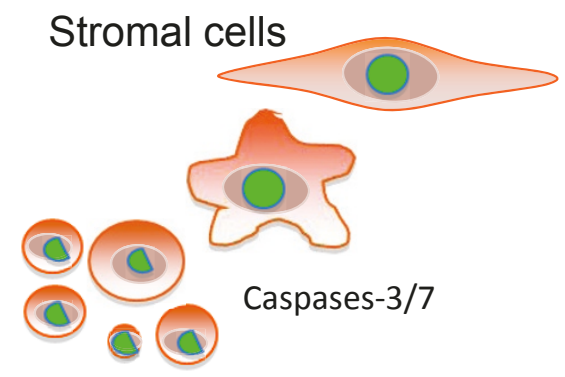

IL-33

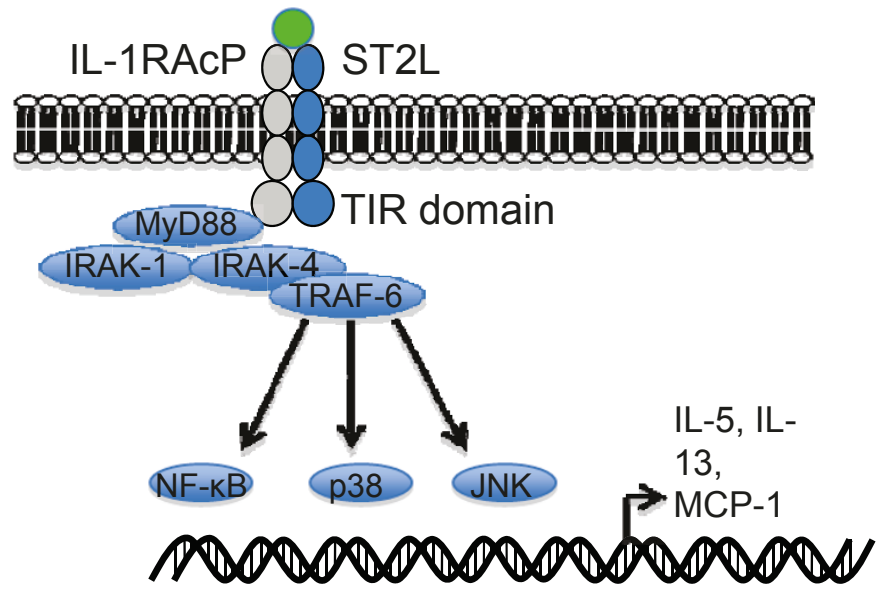

Figure 1 IL-33 release and signaling via ST2L. IL-33 is predominantly expressed by stromal cells such as epithelial and endothelial cells. Damage to these cells can induce necrosis and release of full length IL-33 which can activate the heterodimeric ST2L/LL-1RAcP receptor complex on a variety of immune cells or be neutralized by binding to SST2. During apoptosis IL-33 is cleaved by caspases-3/7 leading to its inactivation. Upon activation of ST2L MyD88 and IRAK-1/4 are recruited and this leads to activation of the transcription factor nuclear factor- $\kappa$ B $(\mathrm{NF}-\kappa \mathrm{B})$ and the mitogen-activated protein kinase (MAPK) pathway, which is mediated by the activation of the MAPKs extracellular signalregulated kinase (ERK), p38 and JUN N-terminal kinase (JNK) and ultimately to the production of Th2 cytokines and chemokines.

caspase-1 [3]. However, recent studies suggest that proteolytic processing is not required for IL-33 signaling via ST2L [13]. Furthermore, it has been suggested that a new splice variant of IL-33 exists, which lacks the putative caspase- 1 cleavage site, and is biologically active inducing signaling via ST2L [14]. In fact, cleavage of IL33 by caspases appears to mediate inactivation of IL-33 and its pro-inflammatory properties [13,15-17]. Currently, it is thought that full length biologically active IL-33 may be released during necrosis as a endogenous danger signal or 'alarmin', but during apoptosis IL-33 is cleaved by caspases leading to inactivation of its pro-inflammatory properties [18].

\section{IL-33, an inducer of Th2 immune responses}

Unlike the other IL-1 family members IL-33 primarily induces $\mathrm{T}$ helper 2 (Th2) immune responses in a number of immune cell types (reviewed in detail in [19]). ST2L was initially shown to be selectively expressed on Th2, but not Th1 $[20,21]$ or regulatory (Treg) T cells [22]. Subsequent studies have shown that IL-33 can activate murine dendritic cells directly driving polarization 
of naïve T cells towards a Th2 phenotype [23], and it can act directly on Th2 cells to increase secretion of Th2 cytokines such as IL-5 and IL-13 [3,24]. Furthermore, IL-33 can also act as a chemo-attractant for Th2 cells [25]. IL-33 can activate B1 B cells in vivo, markedly enhancing production of IgM antibodies and IL-5 and IL-13 production from these cells [3,26,27].

IL-33 is also a potent activator of the innate immune system. Schmitz and co-workers demonstrated that injection of IL-33 into mice induces a profound eosinophilia [3], and has potent effects on this cell type, including induction of superoxide anion and IL- 8 production, degranulation and cell survival [28]. Subsequently, it has been shown that IL-33 is also a potent activator of mast cells and basophils and can induce degranulation, maturation, promote survival and the production of several pro-inflammatory cytokines in these cells [29-32]. In neutrophils, IL-33 prevents the down-regulation of CXCR2 and inhibition of chemotaxis induced by the activation of TLR4 [33]. Macrophages constitutively express ST2L and IL-33 can amplify an IL-13-driven polarization of macrophages towards an alternatively activated or M2 phenotype, thus enhancing Th2 immune responses [34]. IL-33 can also enhance LPS-induced production of TNF $\alpha$ in these cells [35].

It is likely that the primary role of these IL-33 effects on the immune system in evolutionary terms was in host defense against pathogens. In fact, IL-33/ST2 have been shown to be highly expressed and protective several parasite infections in animal models in which Th2 cells are host protective, including Leishmania major [36,37], Toxoplasma gondii [38], Trichuris muris [39], and Nippostrongylus brasiliensis [40]. Furthermore, a recent discovery has highlighted a new population of cells named nuocytes which expand in response to IL33 and represent the predominant early source of IL-13 during helminth infection with Nippostrongylus brasiliensis [41]. However, it is clear that the potent activatory effects of IL-33 on several immune cell types is likely to impact on various inflammatory diseases.

\section{Role of the IL-33/ST2 pathway in inflammatory diseases Asthma}

Asthma is a chronic inflammatory disease classically characterized by airway hyper-responsiveness, allergic inflammation, elevated serum IgE levels, and increased Th2 cytokine production. Given that IL-33 is a strong inducer of Th2 immune responses its role in asthma has been extensively studied (reviewed in [42]). Initial gene expression studies in a range of tissues using human and mouse cDNA libraries revealed expression of IL-33 in lung tissue, and high expression in bronchial smooth muscle cells [3]. More recently, expression of IL-33 was found in higher levels in endobronchial biopsies from human asthmatic subjects compared to controls. The IL-33 expression was particularly evident in those with severe asthma [43], and the expression was mainly located in bronchial epithelial cells [44]. Studies to investigate which cells were the main IL-33 responsive cells in lung demonstrated that both epithelial and endothelial cells, but not smooth muscle cells or fibroblasts were important [45]. Several animal model studies have highlighted a functionally important role for IL-33/ST2 in asthma and allergic airways inflammation. In a murine ovalbumin-induced airway inflammation model, intranasal administration of IL-33 induces antigen-specific IL- $5^{+}$ $\mathrm{T}$ cells and promotes allergic airway disease even in the absence of IL-4 [24]. Furthermore, intranasal IL-33 also promotes airways hyper-responsiveness, goblet cell hyperplasia, eosinophilia, polarization of macrophages towards an M2 phenotype, and accumulation of lung IL-4, IL-5 and IL-13 [34,46,47]. More recently, an IL-33 transgenic mouse was generated in which IL-33 expression was controlled under a CMV promoter and released as a cleaved $18 \mathrm{kDa}$ protein in pulmonary tissue [48]. These mice developed massive airway inflammation with infiltration of eosinophils, hyperplasia of goblet cells and accumulation of pro-inflammatory cytokines in bronchoalveolar lavage fluid. In contrast, intraperitoneal antiIL-33 antibody treatment inhibited allergen-induced lung eosinophilic inflammation and mucus hypersecretion in a murine model [49]. Furthermore, administration of blocking anti-ST2 antibodies or ST2-Ig fusion protein inhibited Th2 cytokine production in vivo, eosinophilic pulmonary inflammation and airways hyper-responsiveness [50]. At present, the role of IL-33/ST2 in studies using ST2-deficient mice is unclear as these mice are not protected in the ovalbumin-induced airway inflammation model but have attenuated inflammation in a short-term priming model of asthma. Furthermore, there is also an exacerbation of disease in wild-type or Rag- $1^{-1-}$ mice that had undergone adoptive transfer of ST2 ${ }^{-1-}$ DO11.10 Th2 cells $[24,51,52]$. In order to clarify the role of IL-33/ST2 in lung inflammation, several groups have generated mice deficient in IL-33. Oboki and co-workers demonstrated that 2 sensitizations of IL-33/- mice with ovalbumin emulsified in alum showed attenuated eosinophil and lymphocyte recruitment to the lung, airway hyperresponsiveness and inflammation [19]. A similar study by Louten and colleagues has also shown that endogenous IL-33 contributes to airway inflammation and peripheral antigen-specific responses in ovalbumin-induced acute allergic lung inflammation using IL-33/- mice [53]. Collectively, the data suggest that IL-33 is involved in lung inflammation and supports the concept of ST2 as a therapeutic target in asthma. 


\section{Rheumatological diseases}

Recent evidence suggests a role for IL-33/ST2 in several rheumatological diseases, including rheumatoid arthritis (RA), osteoarthritis (OA), psoriatic arthritis (PsA) and systemic lupus erythematosus (SLE). The first study to link IL-33 expression with arthritis utilized in situ hybridization to show that IL-33 mRNA expression in the RA synovium is primarily in endothelial cells [11]. Subsequently, IL-33 protein has been found in endothelial cells of synovial tissue and in cells morphologically consistent with synovial fibroblasts in a subset of RA, PsA and OA patients [54]. IL-33 is also expressed in cultured synovial fibroblasts from patients with RA and expression was markedly elevated in vitro by inflammatory cytokines [55,56]. Circulating IL-33 protein has also been detected in 94/223 RA patient serum samples by ELISA, but was completely absent in healthy controls or OA samples [57]. Furthermore, the level of serum IL-33 decreased after anti-TNF treatment and correlated with production of IgM and RA-related autoantibodies including Rheumatoid Factor and anti-citrullinated protein antibodies. Serum and synovial fluid levels of IL-33 have also been shown to decrease in patients who respond to anti-TNF treatment, while they did not change in non-responders [58]. Similarly, Talabot-Ayer and co-workers show that serum and synovial fluid IL-33 levels were higher in RA than in OA patients, and undetectable in PsA serum and synovial fluid [54]. Another study has demonstrated that neutrophils from patients with RA successfully treated with anti-TNF treatment expressed significantly lower levels of ST2 than patients treated with methotrexate alone [59]. In SLE, one study has shown serum IL-33 levels were significantly increased, compared with healthy controls, but to a lower extent than in patients with RA [60]. The other study reported no change in serum IL-33 levels between controls and SLE patients, but did report a significant increase in SST2 that correlated with SLE disease activity [61].

In murine models of RA, IL-33 mRNA has also been detected in the joints of mice undergoing collageninduced arthritis (CIA) [56], and in mouse knee joints injected with methylated bovine serum albumin [59]. Furthermore, $\mathrm{ST}_{2}{ }^{-1}$ mice developed attenuated CIA and reduced ex vivo collagen-specific induction of proinflammatory cytokines (IL-17, TNF $\alpha$, and IFN $\gamma$ ), and antibody production [55]. Conversely, treatment with IL-33 exacerbated CIA and elevated production of both pro-inflammatory cytokines and anti-collagen antibodies through a mast cell-dependent pathway. Administration of blocking anti-ST2 antibodies at the onset of CIA also attenuated the severity of disease and reduced joint destruction [56]. This was also associated with reduced IFN $\gamma$ and IL-17 production. In a model of anti-glucose- 6-phosphate isomerase autoantibody-induced arthritis, IL-33 treatment exacerbated disease. Conversely, ST2 ${ }^{-1-}$ mice were protected against disease and had reduced expression of articular pro-inflammatory cytokines [62]. The IL-33 effects in this model also appear to be mast cell-dependent as IL-33 failed to increase the severity of the disease in mast cell-deficient mice, and mast cells from wild-type, but not $\mathrm{ST}_{2}^{-1-}$ mice restored the ability of $\mathrm{ST}_{2}{ }^{-1-}$ recipients to respond. IL-33 has also been shown to chemoattract neutrophils to a knee joint injected with methylated bovine serum albumin [59].

Various rheumatological diseases can have effects on bone including erosion (e.g. RA) and ossification and the formation of new bone (e.g., ankylosing spondylitis and OA). Recently, the role of IL-33 in bone metabolism and remodeling has been studied with conflicting results. Bone structure and metabolism are determined by the formation and activity of osteoclasts and osteoblasts. Mun and co-workers showed that IL-33 can stimulate the formation of multi-nuclear osteoclasts from monocytes, and enhanced expression of osteoclast differentiation factors including TRAF6, nuclear factor of activated $\mathrm{T}$ cells cytoplasmic 1 , c-Fos, c-Src, cathepsin $\mathrm{K}$, and calcitonin receptor [63]. However, in contrast two other studies have shown that IL-33 completely abolished the generation of multinucleated osteoclasts [64] or had no direct effect $[65,66]$.

IL-33 also appears to have direct effects on osteoblast cells. IL-33 expression increases during osteoblast differentiation, and that while $\mathrm{ST}_{2}^{-/}$mice displayed normal bone formation they had increased bone resorption, thereby resulting in low trabecular bone mass [64]. Furthermore, IL-33 mRNA levels are increased in osteoblasts following treatment with the bone anabolic factors parathyroid hormone or oncostatin M. In addition, IL33 treatment promoted matrix mineral deposition by osteoblasts in vitro [65]. However, a recent study reports conflicting data that while IL-33 mRNA is present in human osteoblasts, ST2L is not constitutively expressed and IL-33 treatment has no effect on these cells [66]. The reasons for these differences in the biology of IL-33 in osteoclasts and osteoblasts are unclear at present but may reflect different cell culture conditions and differentiation protocols used. In summary, IL-33 appears to have pro-inflammatory effects in various rheumatological diseases activating synovial fibroblasts and mast cells within joints.

\section{Inflammatory skin disorders}

Skin and activated dermal fibroblasts contain a high level of IL-33 mRNA expression compared to other tissues and cell types [3]. IL-33 mRNA and protein is also substantially higher in the skin lesions of patients with atopic dermatitis compared with non-inflamed skin samples [67], and in affected psoriatic skin compared to 
healthy skin $[68,69]$. Elevated serum IL-33 levels have also been detected in patients with systemic sclerosis, and levels correlated positively with the extent of skin sclerosis [70]. Furthermore, subcutaneous administration of IL-33 can induce IL-13-dependent fibrosis of skin in murine models [71]. Recently, it was shown that ST2 ${ }^{-1-}$ mice exhibited reduced cutaneous inflammatory responses compared to WT mice in a phorbol esterinduced model of skin inflammation [69]. Furthermore, intradermal injections of IL-33 into the ears of mice induced a psoriasis-like inflammatory lesion that was partially dependent on mast cells.

In addition, IL-33 expression was induced in pericytes in an experimental model of wound healing in rat skin [72]. Surprisingly, IL-33 has also been shown to induce cutaneous hypernociception in mice, a phenomenon traditionally associated with Th1 responses [73]. Collectively, these results demonstrate that IL-33 may play a role in various inflammatory skin disorders (Figure 2).

\section{Inflammatory bowel disease (IBD)}

IBD is a group of chronic inflammatory conditions of the colon and small intestine, including ulcerative colitis (UC) and Crohn's disease, resulting from dysregulated immune responses. Several studies report an upregulation of IL-33 mRNA in human biopsy specimens from untreated or active UC patients compared to controls [72,74-77]. The main sites of UC IL-33 expression were myofibroblasts and epithelial cells. Similarly, ST2 transcripts have been detected in mucosa samples from patients with active UC [74,75]. However, although Carriere and co-workers demonstrated expression of IL-33 in endothelial cells of Crohn's disease intenstine [11], subsequent studies have failed to demonstrate a significant role for IL-33 in Crohn's disease [72,74,76]. Serum IL-33 and sST2 levels were elevated in UC patients compared with controls, while anti-TNF treatment decreased circulating IL-33 and increased sST2, thus favorably altering the ratio of the cytokine with its decoy receptor [74]. However, in other studies serum concentrations of IL-33 were low or did not differ between UC patients and healthy controls [75,78].

Several murine studies highlight a role for IL-33 in innate-type immunity in the gut. Mice treated with IL33 displayed epithelial hyperplasia and eosinophil/neutrophil infiltration in the colonic mucosa [3]. Furthermore, in a murine model of $\mathrm{T}$-cell independent dextran sodium sulphate (DSS)-induced colitis IL-33/- mice had enhanced viability, compared to wild-type controls [19]. In a related study macrophage-specific transgenic mice that express a truncated TGF- $\beta$ receptor II under control of the CD68 promoter (CD68TGF- $\beta$ DNRII) and subjected to the DSS model of colitis display an impaired ability to resolve colitic inflammation but also an increase in $\mathrm{IL}_{-} 33^{+}$macrophages compared to controls [79]. In addition, IL-33 mRNA is upregulated in the ilea and correlates with disease severity in a murine model of Th1/Th2-mediated enteritis, and induced IL-17 production from mesenteric lymph node cells stimulated ex vivo [74]. In summary, the IL-33/ST2 pathway may be an important regulator of UC, but be of less importance in Crohn's disease.

\section{Central nervous system (CNS) inflammation}

Basal IL-33 mRNA levels are extremely high in the brain and spinal cord [3], and are elevated under conditions such as experimental subarachnoid hemorrhage [1]. Furthermore, expression of IL-33 in glial and astrocyte cultures is increased by Toll-like receptor ligands [80]. Treatment with IL-33 induces proliferation of microglia and enhances production of pro-inflammatory cytokines, such as IL- $1 \beta$ and TNF $\alpha$, as well as the anti-inflammatory cytokine IL-10 [81]. It also enhances chemokines and nitric oxide production and phagocytosis by microglia. In mice, IL-33 levels and activity were increased in brains infected with the neurotropic virus Theiler's murine encephalomyelitis virus [80]. Finally, a transcriptional analysis of brain tissue from patients with Alzheimer's disease revealed that IL-33 expression was decreased compared to control tissues [82]. This study also demonstrated that 3 polymorphisms within the IL33 gene resulting in a protective haplotype were associated with risk of Alzheimer's disease [82]. This data is supported by a study in Chinese population with evidence that genetic variants of IL-33 affect susceptibility to Alzheimer's disease [83]. Furthermore, cell-based assays demonstrate that IL-33 can decrease secretion of $\beta$-amyloid peptides [82]. Thus, IL-33 may have a role in regulating pathophysiology and inflammatory responses in the CNS.

\section{Cancer}

Although early reports document the expression of ST2 on leukaemic cell lines and on $\mathrm{T}$ cell lymphomas of patients $[84,85]$, very few studies have addressed the role of IL-33/ST2 signaling on anti-tumor immune responses, tumor growth and/or metastasis. However, a recent study demonstrated that $\mathrm{ST} 2^{-1-}$ mice with mammary tumors have attenuated tumor growth and metastasis, with increased circulating levels of proinflammatory cytokines and activated $\mathrm{NK}$ and $\mathrm{CD} 8^{+} \mathrm{T}$ cells [86]. Furthermore, IL-33 induces proliferation, migration, and morphologic differentiation of endothelial cells, consistent with an effect on angiogenesis [87]. In addition, IL-33 expression is present in endothelial cells of healthy organs but is strikingly absent from those in tumors [88]. Therefore, IL-33 may be an important mediator in tumor escape from immune control and in tumor angiogenesis and thus warrants further investigation. 


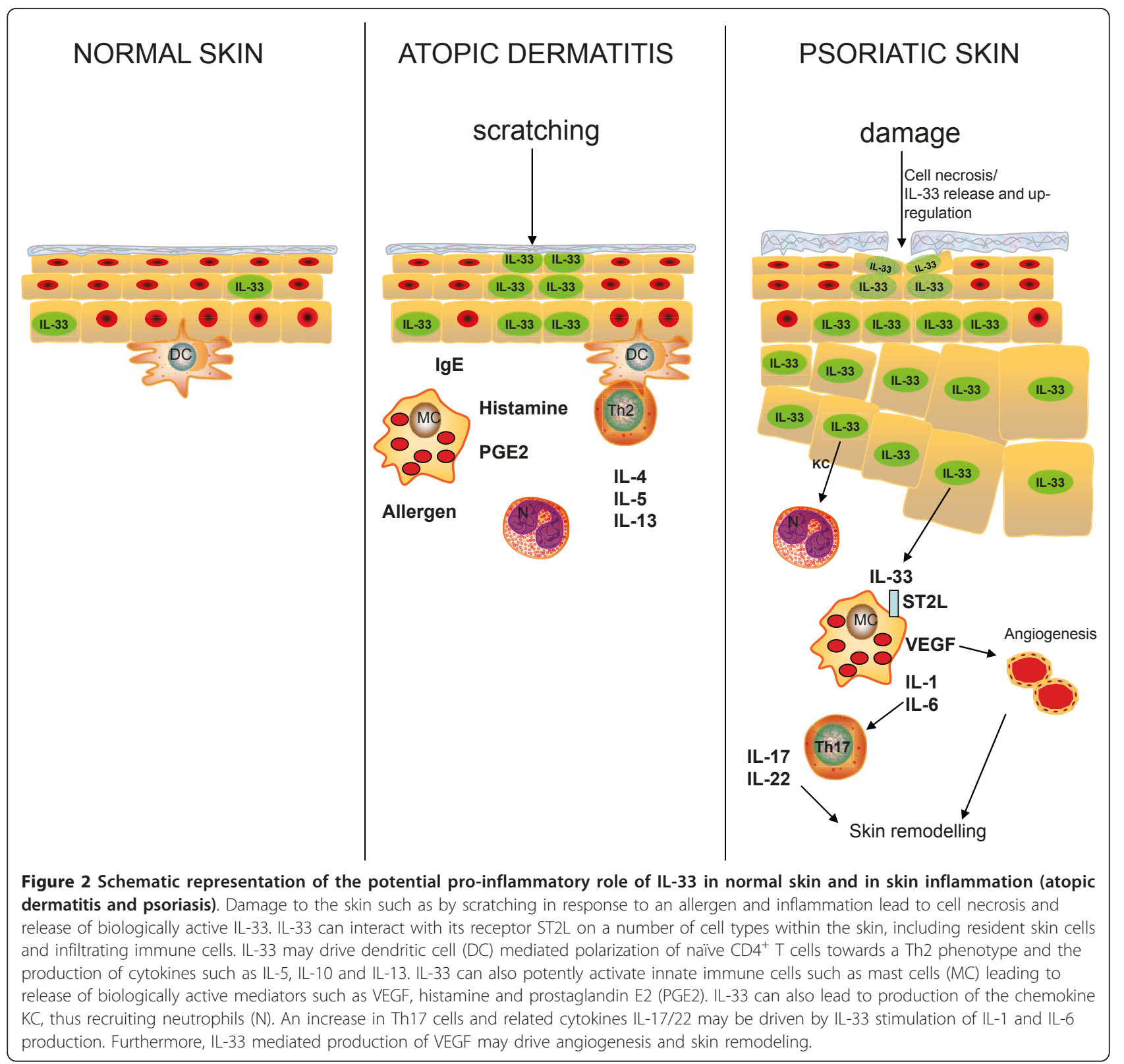

\section{Cardiovascular (CV) disease}

IL-33 was initially found in the nucleus of the high endothelial venules (HEV) of secondary lymphoid tissues [2]. More recently, IL-33 expression has been reported in coronary artery smooth muscle cells [3], coronary artery endothelium [89], non-HEV endothelial cells $[88,90]$, adipocytes $[66,91]$, and in cardiac fibroblasts suggesting that IL-33 may play a role in various CV disorders [92].

sST2 as a CV biomarker This concept is supported by the clinical finding that the IL-33 decoy receptor sST2 was elevated in serum early after acute myocardial infarction (AMI), and correlated with creatine kinase and inversely correlated with left ventricular ejection fraction [93]. Since this primary observation several studies have since demonstrated the prognostic value of measuring serum sST2 in various $\mathrm{CV}$ diseases, showing that high baseline levels of sST2 were a significant predictor of CV mortality and heart failure (HF) (Table 1). Taken together, these studies indicate that sST2 has the potential to be a predictive CV biomarker in patients with AMI, HF and dyspnea. Thus far, serum or plasma IL-33 has not been measured in CV disease. While levels are elevated in atopy [67], and some rheumatological diseases $[57,58]$, the levels in CV disease are likely to be low (possibly due to elevated sST2 levels) and difficult to measure with currently available assays. However, recent studies have highlighted the development of 
Table 1 Studies examining SST2 in serum/plasma of patients with CV disease

\begin{tabular}{|c|c|c|}
\hline Disease & Result & Ref. \\
\hline \multirow[t]{3}{*}{ AMl } & - sST2 levels were increased in the serum of patients 1 day after AMI. & [93] \\
\hline & - ST2 levels predicted subsequent mortality and HF in patients admitted with AMI (TIMI, STEMI \& CLARITY-TIMI trials). & {$[103,104]$} \\
\hline & - sST2 levels predicted adverse left ventricular functional recovery and remodeling post-AMI. & [105] \\
\hline $\begin{array}{l}\text { Acute chest } \\
\text { pain }\end{array}$ & $\begin{array}{l}\text { - Measurement of sST2 was of no prognostic value in the prediction of AMI, acute coronary syndromes or 30-day } \\
\text { events in patients presenting to the emergency department with chest pain. }\end{array}$ & [106] \\
\hline \multirow[t]{9}{*}{ HF } & $\begin{array}{l}\text { - PRAISE-2 HF trial and showed that the change in SST2 levels was an independent predictor of subsequent mortality } \\
\text { or transplantation in patients with severe chronic HF. }\end{array}$ & [107] \\
\hline & - Increased plasma concentrations of sST2 are predictive for 1-year mortality in patients with acute destabilized HF. & [108] \\
\hline & - sST2 levels correlated with the severity of HF and left ventricular ejection fraction. & [109] \\
\hline & $\begin{array}{l}\text { - Serial sampling of sST2 demonstrated that the \% change in SST2 concentrations during acute HF treatment is } \\
\text { predictive of 90-day mortality. }\end{array}$ & [110] \\
\hline & - Elevated sST2 concentrations are predictive of sudden cardiac death in patients with chronic HF. & [111] \\
\hline & - Pleural fluid SST2 levels were not helpful for diagnosing effusions due to HF. & [112] \\
\hline & - sST2 levels were lower in decompensated HF patients who did not have a sudden cardiac event. & [113] \\
\hline & $\begin{array}{l}\text { - sST2 levels were greater in patients with systolic HF than in those with acutely decompensated HF with preserved } \\
\text { ejection fraction. }\end{array}$ & [114] \\
\hline & $\begin{array}{l}\text { - Chronic HF patients whose sST2 levels were in the highest had a markedly increased risk of adverse outcomes } \\
\text { compared with the lowest tertile. }\end{array}$ & [115] \\
\hline $\begin{array}{l}\text { Cardiac } \\
\text { Surgery }\end{array}$ & $\begin{array}{l}\text { - Cardiac surgery patients undergoing coronary artery bypass grafting with cardiopulmonary bypass demonstrate a } \\
\text { significant rise in SST2 levels } 24 \text { hours after surgery. }\end{array}$ & {$[116,117]$} \\
\hline $\begin{array}{l}\text { Outpatient } \\
\text { study }\end{array}$ & $\begin{array}{l}\text { - In an outpatient study sST2 levels also reflected right-side heart size and function and were an independent } \\
\text { predictor of } 1 \text {-year mortality in outpatients referred for echocardiograms. }\end{array}$ & [118] \\
\hline \multirow[t]{2}{*}{ Dyspnea } & - sST2 concentration strongly predicted death at 1 year in dyspneic patients. & {$[119-122]$} \\
\hline & $\begin{array}{l}\text { - sST2 concentrations are associated with cardiac abnormalities on echocardiography, a more decompensated } \\
\text { hemodynamic profile and are associated with long-term mortality in dyspneic patients. }\end{array}$ & [123] \\
\hline
\end{tabular}

AMI - Acute Myocardial Infarction; HF - Heart Failure

multiplex assays to measure low abundance IL-33 in serum or plasma and warrant further investigation in the context of CV disease [94]. In summary, sST2 shows promise as a biomarker predictive of mortality in several CV disorders.

Cardiac fibrosis and hypertrophy Studies in animal models suggest that sST2 is more than just a marker in CV disease and implicate IL-33/ST2 signaling as an important protective pathway in various CV diseases. In a model of pressure overload IL-33 treatment reduced cardiac hypertrophy and fibrosis, and improved survival following transverse aortic constriction in wild-type but not $\mathrm{ST}^{-/-}$mice [92]. Furthermore, sST2 blocked the antihypertrophic effects of IL-33, indicating that sST2 functions in the myocardium as a soluble decoy receptor of IL-33. IL-33 can also reduce cardiomyocyte apoptosis, decrease infarct and fibrosis, and improve ventricular function in vivo via suppression of caspase-3 activity and increased expression of the 'inhibitor of apoptosis' family of proteins [95]. The protective effects of IL-33 may be limited by the neurohormonal factor endothelin-1, which increased expression of sST2 and inhibited IL-33 signaling through p38 MAP Kinase [96].

Atherosclerosis During atherosclerosis immune cells such as monocytes, $\mathrm{T}$ cells and mast cells infiltrate plaques within the intima of the arterial wall [97]. The disease appears to be driven by a Th1 immune response with cytokines such as IL-12 and IFN $\gamma$ inducing pathogenesis $[98,99]$. Thus, it was hypothesized that IL-33 may have protective effects during atherosclerosis by inducing a Th1-to-Th2 switch of immune responses. In fact, treatment of $\mathrm{ApoE}^{-1-}$ mice with IL-33 significantly reduced atherosclerotic lesion size in the aortic sinus and reduced plaque $\mathrm{F} 4 / 80^{+}$macrophage and $\mathrm{CD}^{+} \mathrm{T}$ cell content [26]. IL-33 treatment increased levels of the Th2 cytokines IL-4, IL-5, and IL-13 but decreased levels of the Th1 cytokine IFN $\gamma$ in serum and lymph node cells. Furthermore, IL-33-treated ApoE ${ }^{-/-}$mice also produced significantly elevated levels of protective anti-oxidized lowdensity lipoprotein (ox-LDL) IgM antibodies. Conversely, mice treated with intraperitoneal injections of sST2 developed significantly larger atherosclerotic plaques and enhanced IFN $\gamma$ levels. Thus far, atherosclerosis development has not been studied in $\mathrm{ApoE}^{-/-}$or $\mathrm{LDLR}^{-/-}$mice also deficient in genes encoding either IL-33 or ST2 and these studies are required in order to examine the endogenous role of IL-33. Cell-based experiments have also shown that IL-33 has potent effects on macrophagederived foam cell function in vitro providing further evidence for anti-atherosclerotic effects of IL-33 [100]. 
Taken together these results indicate that IL-33/ST2 signaling may play a protective role in atherosclerosis.

Obesity and type 2 diabetes Recently, expression of IL33 and ST2 was reported in adipocytes and adipose tissues $[66,91]$. Subsequently it was shown that treatment of adipocyte cultures in vitro with IL-33 induced the production of Th2 cytokines (IL-5 and IL-13), reduced lipid storage and decreased the expression of several genes associated with lipid metabolism and adipogenesis (e.g. C/EBP $\alpha$, SREBP-1c, LXR $\alpha, L X R \beta$, and PPAR $\gamma$ ) [101]. Furthermore, treatment of genetically obese diabetic $(o b / o b)$ mice with IL-33 led to protective metabolic effects with reduced adiposity, reduced fasting glucose and improved glucose and insulin tolerance [101]. Conversely, $\mathrm{ST}^{-/-}$mice fed high fat diet for 6 months had increased body weight and fat mass, impaired insulin secretion and glucose regulation compared to wild-type controls. The protective effects of IL-33 on adipose tissue appear to be mediated via an increased production of Th2 cytokines and a switching of macrophage polarization from an M1 to an M2 phenotype (Figure 3).
More recently, a newly identified population of cells expressing ST2 were found in adipose named natural helper cells or fat-associated lymphoid cluster (FALC) cells that produce large amounts of Th2 cytokines in response to IL-33 [102], but the direct role of these cells in obesity is still unclear.

\section{Conclusions}

IL-33 appears to be a crucial cytokine for Th2-mediated host defense and plays a central role in controlling immune responses in barrier tissues such as skin and intestine. It is able to activate cells of both the innate and adaptive immune system, and depending on the disease can either promote the resolution of inflammation or drive disease pathology. Manipulation of the IL-33/ ST2 pathway therefore represents a promising new therapeutic strategy for treating or preventing various inflammatory disorders. However, many questions regarding the fundamental biology of IL-33 remain to be solved, including its nuclear effects and processing and release of IL-33 from cells. Furthermore, given the

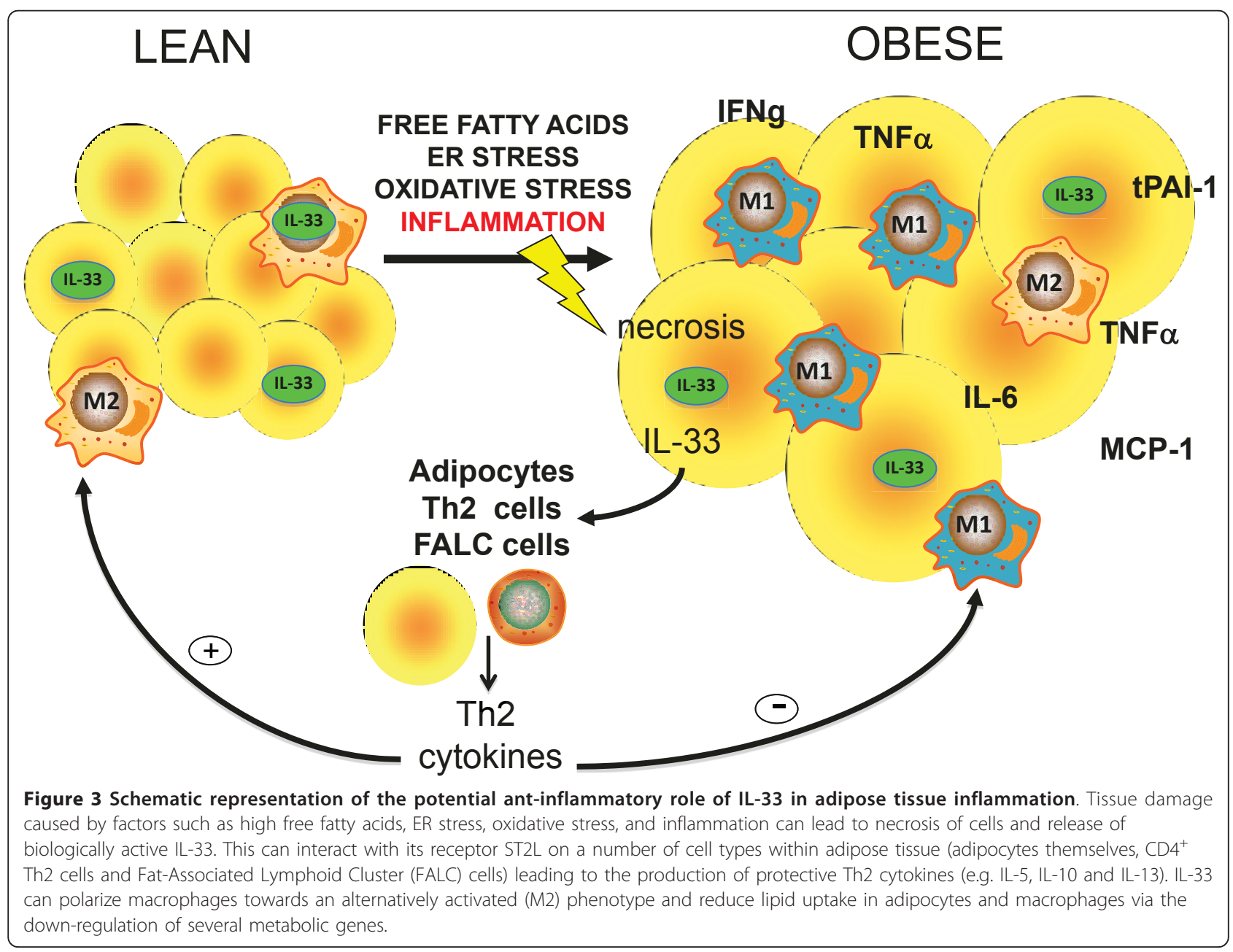


wide variety of cellular responses regulated by IL-33 and ST2, and in particular the cardio-protective effects of IL-33, this should be approached with caution.

\section{List of abbreviations}

AMI: Acute myocardial infarction; CIA: Collagen-induced arthritis; CNS: Central nervous system; CV: Cardiovascular; HEV: High endothelial venules; HF: Heart failure; IL: Interleukin; IL:1RAcP- IL:1R accessory protein; MAPK: Mitogenactivated protein kinase; OA: Osteoarthritis; PsA: Psoriatic arthritis; RA: Rheumatoid arthritis; SIGIRR: Single Ig IL:1R-related molecule; SLE: Systemic lupus erythematosus; SST2: Soluble ST2; Th: T helper; TIR: Toll-interleukin-1 receptor; TLR: Toll-like receptor; UC: Ulcerative colitis

\section{Acknowledgements and funding}

AM Miller is supported by a BHF Intermediate Basic Science Research Fellowship (FS/08/035/25309).

\section{Competing interests}

The authors declare that they have no competing interests.

Received: 1 May 2011 Accepted: 26 August 2011

Published: 26 August 2011

\section{References}

1. Onda H, Kasuya H, Takakura K, Hori T, Imaizumi T, Takeuchi T, Inoue I, Takeda J: Identification of genes differentially expressed in canine vasospastic cerebral arteries after subarachnoid hemorrhage. J Cereb Blood Flow Metab 1999, 19:1279-1288.

2. Baekkevold ES, Roussigne M, Yamanaka T, Johansen FE, Jahnsen FL, Amalric F, Brandtzaeg P, Erard M, Haraldsen G, Girard JP: Molecular characterization of NF-HEV, a nuclear factor preferentially expressed in human high endothelial venules. Am J Pathol 2003, 163:69-79.

3. Schmitz J, Owyang A, Oldham E, Song Y, Murphy E, McClanahan TK, Zurawski G, Moshrefi M, Qin J, Li X, et al: IL-33, an interleukin-1-like cytokine that signals via the IL-1 receptor-related protein ST2 and induces T helper type 2-associated cytokines. Immunity 2005, 23:479-490.

4. Chackerian AA, Oldham ER, Murphy EE, Schmitz J, Pflanz S, Kastelein RA: IL1 receptor accessory protein and ST2 comprise the IL-33 receptor complex. J Immunol 2007, 179:2551-2555.

5. Ali S, Huber M, Kollewe C, Bischoff SC, Falk W, Martin MU: IL-1 receptor accessory protein is essential for IL-33-induced activation of T lymphocytes and mast cells. Proc Natl Acad Sci USA 2007, 104:18660-18665.

6. Palmer G, Lipsky BP, Smithgall MD, Meininger D, Siu S, Talabot-Ayer D, Gabay C, Smith DE: The IL-1 receptor accessory protein (AcP) is required for IL-33 signaling and soluble AcP enhances the ability of soluble ST2 to inhibit IL-33. Cytokine 2008, 42:358-364.

7. Hayakawa H, Hayakawa M, Kume A, Tominaga S: Soluble ST2 blocks interleukin-33 signaling in allergic airway inflammation. J Biol Chem 2007, 282:26369-26380.

8. Tago K, Noda T, Hayakawa M, Iwahana H, Yanagisawa K, Yashiro T, Tominaga S: Tissue distribution and subcellular localization of a variant form of the human ST2 gene product, ST2V. Biochem Biophys Res Commun 2001, 285:1377-1383.

9. Bulek K, Swaidani S, Qin J, Lu Y, Gulen MF, Herjan T, Min B, Kastelein RA, Aronica M, Kosz-Vnenchak M, Li X: The essential role of single Ig IL-1 receptor-related molecule/Toll IL-1R8 in regulation of Th2 immune response. J Immunol 2009, 182:2601-2609.

10. Haraldsen G, Balogh J, Pollheimer J, Sponheim J, Kuchler AM: Interleukin-33 - cytokine of dual function or novel alarmin? Trends Immunol 2009, 30:227-233.

11. Carriere V, Roussel L, Ortega N, Lacorre DA, Americh L, Aguilar L, Bouche G, Girard JP: IL-33, the IL-1-like cytokine ligand for ST2 receptor, is a chromatin-associated nuclear factor in vivo. Proc Natl Acad Sci USA 2007, 104:282-287.

12. Roussel L, Erard M, Cayrol C, Girard JP: Molecular mimicry between IL-33 and KSHV for attachment to chromatin through the H2A-H2B acidic pocket. EMBO Rep 2008, 9:1006-1012.
13. Talabot-Ayer D, Lamacchia C, Gabay C, Palmer G: Interleukin-33 is biologically active independently of caspase-1 cleavage. $J$ Biol Chem 2009, 284:19420-19426.

14. Hong J, Bae S, Jhun H, Lee S, Choi J, Kang T, Kwak A, Hong K, Kim E, Jo S, Kim S: Identification of constitutively active IL-33 splice variant. J Biol Chem 2011.

15. Cayrol C, Girard JP: The IL-1-like cytokine IL-33 is inactivated after maturation by caspase-1. Proc Natl Acad Sci USA 2009, 106:9021-9026.

16. Luthi AU, Cullen SP, McNeela EA, Duriez PJ, Afonina IS, Sheridan C, Brumatti G, Taylor RC, Kersse K, Vandenabeele P, et al: Suppression of interleukin-33 bioactivity through proteolysis by apoptotic caspases. Immunity 2009, 31:84-98.

17. Ohno T, Oboki K, Kajiwara N, Morii E, Aozasa K, Flavell RA, Okumura K, Saito H, Nakae S: Caspase-1, caspase-8, and calpain are dispensable for IL-33 release by macrophages. J Immunol 2009, 183:7890-7897.

18. Lamkanfi M. Dixit VM: IL-33 raises alarm. Immunity 2009, 31:5-7.

19. Oboki K, Ohno T, Kajiwara N, Arae K, Morita H, Ishii A, Nambu A, Abe T, Kiyonari $\mathrm{H}$, Matsumoto $\mathrm{K}$, et al: IL-33 is a crucial amplifier of innate rather than acquired immunity. Proc Natl Acad Sci USA 2010, 107:18581-18586.

20. Xu D, Chan WL, Leung BP, Huang F, Wheeler R, Piedrafita D, Robinson JH, Liew FY: Selective expression of a stable cell surface molecule on type 2 but not type 1 helper T cells. J Exp Med 1998, 187:787-794.

21. Lohning M, Stroehmann A, Coyle AJ, Grogan JL, Lin S, Gutierrez-Ramos JC, Levinson D, Radbruch A, Kamradt T: T1/ST2 is preferentially expressed on murine Th2 cells, independent of interleukin 4, interleukin 5, and interleukin 10, and important for Th2 effector function. Proc Natl Acad Sci USA 1998, 95:6930-6935.

22. Lecart S, Lecointe N, Subramaniam A, Alkan S, Ni D, Chen R, Boulay V, Pene J, Kuroiwa K, Tominaga S, Yssel H: Activated, but not resting human Th2 cells, in contrast to Th1 and T regulatory cells, produce soluble ST2 and express low levels of ST2L at the cell surface. Eur J Immunol 2002, 32:2979-2987.

23. Rank MA, Kobayashi T, Kozaki H, Bartemes KR, Squillace DL, Kita H: IL-33activated dendritic cells induce an atypical TH2-type response. J Allergy Clin Immunol 2009, 123:1047-1054.

24. Kurowska-Stolarska M, Kewin P, Murphy G, Russo RC, Stolarski B, Garcia CC, Komai-Koma M, Pitman N, Li Y, Niedbala W, et al: IL-33 induces antigenspecific IL-5+ T cells and promotes allergic-induced airway inflammation independent of IL-4. J Immunol 2008, 181:4780-4790.

25. Komai-Koma M, Xu D, Li Y, McKenzie AN, McInnes IB, Liew FY: IL-33 is a chemoattractant for human Th2 cells. Eur I Immunol 2007, 37:2779-2786,

26. Miller AM, Xu D, Asquith DL, Denby L, Li Y, Sattar N, Baker AH, Mclnnes IB, Liew FY: IL-33 reduces the development of atherosclerosis. J Exp Med 2008, 205:339-346

27. Komai-Koma M, Gilchrist DS, McKenzie AN, Goodyear CS, Xu D, Liew FY: IL33 activates B1 cells and exacerbates contact sensitivity. J Immunol 2011, $186: 2584-2591$

28. Cherry WB, Yoon J, Bartemes KR, lijima K, Kita H: A novel IL-1 family cytokine, IL-33, potently activates human eosinophils. J Allergy Clin Immunol 2008, 121:1484-1490.

29. Allakhverdi Z, Smith DE, Comeau MR, Delespesse G: Cutting edge: The ST2 ligand IL-33 potently activates and drives maturation of human mast cells. J Immunol 2007, 179:2051-2054

30. likura M, Suto H, Kajiwara N, Oboki K, Ohno T, Okayama Y, Saito H, Galli SJ, Nakae S: IL-33 can promote survival, adhesion and cytokine production in human mast cells. Lab Invest 2007, 87:971-978.

31. Smithgall MD, Comeau MR, Yoon BR, Kaufman D, Armitage R, Smith DE: IL33 amplifies both Th1- and Th2-type responses through its activity on human basophils, allergen-reactive Th2 cells, iNKT and NK cells. Int Immunol 2008, 20:1019-1030

32. Schneider E, Petit-Bertron AF, Bricard R, Levasseur M, Ramadan A, Girard JP, Herbelin A, Dy M: IL-33 activates unprimed murine basophils directly in vitro and induces their in vivo expansion indirectly by promoting hematopoietic growth factor production. J Immunol 2009, 183:3591-3597.

33. Alves-Filho JC, Sonego F, Souto FO, Freitas A, Verri WA Jr, AuxiliadoraMartins M, Basile-Filho A, McKenzie AN, Xu D, Cunha FQ, Liew FY: Interleukin-33 attenuates sepsis by enhancing neutrophil influx to the site of infection. Nat Med 2010, 16:708-712.

34. Kurowska-Stolarska M, Stolarski B, Kewin P, Murphy G, Corrigan CJ, Ying S, Pitman N, Mirchandani A, Rana B, van Rooijen N, et al: IL-33 amplifies the 
polarization of alternatively activated macrophages that contribute to airway inflammation. J Immunol 2009, 183:6469-6477.

35. Espinassous Q, Garcia-de-Paco E, Garcia-Verdugo I, Synguelakis M, von Aulock S, Sallenave JM, McKenzie AN, Kanellopoulos J: IL-33 enhances lipopolysaccharide-induced inflammatory cytokine production from mouse macrophages by regulating lipopolysaccharide receptor complex. J Immunol 2009, 183:1446-1455.

36. Kropf P, Bickle Q, Herath S, Klemenz R, Muller I: Organ-specific distribution of CD4+ T1/ST2+ Th2 cells in Leishmania major infection. Eur J Immunol 2002, 32:2450-2459.

37. Kropf $\mathrm{P}$, Herath $\mathrm{S}$, Klemenz R, Muller I: Signaling through the T1/ST2 molecule is not necessary for Th2 differentiation but is important for the regulation of type 1 responses in nonhealing Leishmania major infection. Infect Immun 2003, 71:1961-1971.

38. Jones LA, Roberts F, Nickdel MB, Brombacher F, McKenzie AN, Henriquez FL, Alexander J, Roberts CW: IL-33 receptor (T1/ST2) signalling is necessary to prevent the development of encephalitis in mice infected with Toxoplasma gondii. Eur I Immunol 2010, 40:426-436

39. Humphreys NE, Xu D, Hepworth MR, Liew FY, Grencis RK: IL-33, a potent inducer of adaptive immunity to intestinal nematodes. J Immunol 2008, 180:2443-2449

40. Price AE, Liang HE, Sullivan BM, Reinhardt RL, Eisley CJ, Erle DJ, Locksley RM: Systemically dispersed innate IL-13-expressing cells in type 2 immunity. Proc Natl Acad Sci USA 2010, 107:11489-11494.

41. Neill DR, Wong SH, Bellosi A, Flynn RJ, Daly M, Langford TK, Bucks C, Kane CM, Fallon PG, Pannell $R$, et al: Nuocytes represent a new innate effector leukocyte that mediates type-2 immunity. Nature 2010, 464:1367-1370.

42. Lloyd CM: IL-33 family members and asthma - bridging innate and adaptive immune responses. Curr Opin Immunol 2010, 22:800-806.

43. Prefontaine D, Lajoie-Kadoch S, Foley $S$, Audusseau $S$, Olivenstein $R$, Halayko AJ, Lemiere C, Martin JG, Hamid Q: Increased expression of IL-33 in severe asthma: evidence of expression by airway smooth muscle cells. J Immunol 2009, 183:5094-5103.

44. Prefontaine D, Nadigel J, Chouiali F, Audusseau S, Semlali A, Chakir J, Martin JG, Hamid Q: Increased IL-33 expression by epithelial cells in bronchial asthma. J Allergy Clin Immunol 2010.

45. Yagami A, Orihara K, Morita H, Futamura K, Hashimoto N, Matsumoto K, Saito H, Matsuda A: IL-33 Mediates Inflammatory Responses in Human Lung Tissue Cells. J Immunol 2010.

46. Kondo $\mathrm{Y}$, Yoshimoto $\mathrm{T}$, Yasuda $\mathrm{K}$, Futatsugi-Yumikura $\mathrm{S}$, Morimoto $\mathrm{M}$, Hayashi N, Hoshino T, Fujimoto J, Nakanishi K: Administration of IL-33 induces airway hyperresponsiveness and goblet cell hyperplasia in the lungs in the absence of adaptive immune system. Int Immunol 2008, 20:791-800.

47. Stolarski B, Kurowska-Stolarska M, Kewin P, Xu D, Liew FY: IL-33 exacerbates eosinophil-mediated airway inflammation. J Immunol 2010, 185:3472-3480.

48. Zhiguang X, Wei C, Steven R, Wei D, Wei Z, Rong M, Zhanguo L, Lianfeng Z: Over-expression of IL-33 leads to spontaneous pulmonary inflammation in mlL-33 transgenic mice. Immunol Lett 2010, 131:159-165

49. Liu X, Li M, Wu Y, Zhou Y, Zeng L, Huang T: Anti-IL-33 antibody treatment inhibits airway inflammation in a murine model of allergic asthma. Biochem Biophys Res Commun 2009, 386:181-185.

50. Coyle AJ, Lloyd C, Tian J, Nguyen T, Erikkson C, Wang L, Ottoson P, Persson P, Delaney T, Lehar $S$, et al: Crucial role of the interleukin 1 receptor family member T1/ST2 in T helper cell type 2-mediated lung mucosal immune responses. J Exp Med 1999, 190:895-902.

51. Hoshino K, Kashiwamura S, Kuribayashi K, Kodama T, Tsujimura T, Nakanishi K, Matsuyama T, Takeda K, Akira S: The absence of interleukin 1 receptor-related T1/ST2 does not affect T helper cell type 2 development and its effector function. J Exp Med 1999, 190:1541-1548.

52. Mangan NE, Dasvarma A, McKenzie AN, Fallon PG: T1/ST2 expression on Th2 cells negatively regulates allergic pulmonary inflammation. Eur J Immunol 2007, 37:1302-1312.

53. Louten J, Rankin AL, Li Y, Murphy EE, Beaumont M, Moon C, Bourne P, McClanahan TK, Pflanz S, de Waal Malefyt R: Endogenous IL-33 enhances Th2 cytokine production and T-cell responses during allergic airway inflammation. Int Immunol 2011.

54. Talabot-Ayer D, McKee T, Gindre P, Bas S, Baeten DL, Gabay C, Palmer G: Distinct serum and synovial fluid interleukin (IL)-33 levels in rheumatoid arthritis, psoriatic arthritis and osteoarthritis. Joint Bone Spine 2011.
55. Xu D, Jiang HR, Kewin P, Li Y, Mu R, Fraser AR, Pitman N, KurowskaStolarska M, McKenzie AN, Mclnnes IB, Liew FY: IL-33 exacerbates antigeninduced arthritis by activating mast cells. Proc Natl Acad Sci USA 2008, 105:10913-10918.

56. Palmer G, Talabot-Ayer D, Lamacchia C, Toy D, Seemayer CA, Viatte S, Finckh A, Smith DE, Gabay C: Inhibition of interleukin-33 signaling attenuates the severity of experimental arthritis. Arthritis Rheum 2009, 60:738-749.

57. Mu R, Huang HQ, Li YH, Li C, Ye H, Li ZG: Elevated serum interleukin 33 is associated with autoantibody production in patients with rheumatoid arthritis. J Rheumatol 2010, 37:2006-2013.

58. Matsuyama Y, Okazaki H, Tamemoto H, Kimura H, Kamata Y, Nagatani $K_{\text {, }}$ Nagashima T, Hayakawa M, Iwamoto M, Yoshio T, et al: Increased levels of interleukin 33 in sera and synovial fluid from patients with active rheumatoid arthritis. J Rheumatol 2010, 37:18-25.

59. Verri WA Jr, Souto FO, Vieira SM, Almeida SC, Fukada SY, Xu D, AlvesFilho JC, Cunha TM, Guerrero AT, Mattos-Guimaraes RB, et al: IL-33 induces neutrophil migration in rheumatoid arthritis and is a target of anti-TNF therapy. Ann Rheum Dis 2010, 69:1697-1703.

60. Yang Z, Liang Y, Xi W, Li C, Zhong R: Association of increased serum IL-33 levels with clinical and laboratory characteristics of systemic lupus erythematosus in Chinese population. Clin Exp Med 2010.

61. Mok MY, Huang FP, Ip WK, Lo Y, Wong FY, Chan EY, Lam KF, Xu D: Serum levels of IL-33 and soluble ST2 and their association with disease activity in systemic lupus erythematosus. Rheumatology (Oxford) 2010, 49:520-527.

62. Xu D, Jiang HR, Li Y, Pushparaj PN, Kurowska-Stolarska M, Leung BP, Mu R, Tay HK, McKenzie AN, McInnes IB, et al: IL-33 Exacerbates AutoantibodyInduced Arthritis. J Immunol 2010, 184:2620-2626.

63. Mun SH, Ko NY, Kim HS, Kim JW, Kim do K, Kim AR, Lee SH, Kim YG, Lee CK, Lee SH, et al: Interleukin-33 stimulates formation of functional osteoclasts from human CD14(+) monocytes. Cell Mol Life Sci 2010, 67:3883-3892.

64. Schulze J, Bickert T, Beil FT, Zaiss MM, Albers J, Wintges K, Streichert T, Klaetschke K, Keller J, Hissnauer TN, et al: Interleukin-33 is expressed in differentiated osteoblasts and blocks osteoclast formation from bone marrow precursor cells. J Bone Miner Res 2010.

65. Saleh H, Eeles D, Hodge JM, Nicholson GC, Gu R, Pompolo S, Gillespie MT, Quinn JM: Interleukin-33, a Target of Parathyroid Hormone and Oncostatin M, Increases Osteoblastic Matrix Mineral Deposition and Inhibits Osteoclast Formation in Vitro. Endocrinology 2011.

66. Saidi S, Bouri F, Lencel P, Duplomb L, Baud'huin M, Delplace S, Leterme D, Miellot F, Heymann D, Hardouin P, et al: IL-33 is expressed in human osteoblasts, but has no direct effect on bone remodeling. Cytokine 2011, 53:347-354.

67. Pushparaj PN, Tay HK, H'Ng SC, Pitman N, Xu D, McKenzie A, Liew FY, Melendez AJ: The cytokine interleukin-33 mediates anaphylactic shock. Proc Natl Acad Sci USA 2009, 106:9773-9778.

68. Theoharides TC, Zhang B, Kempuraj D, Tagen M, Vasiadi M, Angelidou A, Alysandratos KD, Kalogeromitros D, Asadi S, Stavrianeas N, et al: IL-33 augments substance P-induced VEGF secretion from human mast cells and is increased in psoriatic skin. Proc Natl Acad Sci USA 2010.

69. Hueber AJ, Alves-Filho JC, Asquith DL, Michels C, Millar NL, Reilly JH, Graham GJ, Miller AM, McInnes IB: IL-33 induces skin inflammation with mast cell and neutrophil activation. Eur J Immunol 2011.

70. Yanaba K, Yoshizaki A, Asano Y, Kadono T, Sato S: Serum IL-33 levels are raised in patients with systemic sclerosis: association with extent of skin sclerosis and severity of pulmonary fibrosis. Clin Rheumatol 2011.

71. Rankin AL, Mumm JB, Murphy E, Turner S, Yu N, McClanahan TK, Bourne PA, Pierce RH, Kastelein R, Pflanz S: IL-33 induces IL-13-dependent cutaneous fibrosis. J Immunol 2010, 184:1526-1535.

72. Sponheim J, Pollheimer J, Olsen T, Balogh J, Hammarstrom C, Loos T, Kasprzycka M, Sorensen DR, Nilsen HR, Kuchler AM, et al: Inflammatory bowel disease-associated interleukin-33 is preferentially expressed in ulceration-associated myofibroblasts. Am J Pathol 2010, 177:2804-2815.

73. Verri WA Jr, Guerrero AT, Fukada SY, Valerio DA, Cunha TM, Xu D, Ferreira SH, Liew FY, Cunha FQ: IL-33 mediates antigen-induced cutaneous and articular hypernociception in mice. Proc Natl Acad Sci USA 2008, 105:2723-2728.

74. Pastorelli L, Garg RR, Hoang SB, Spina L, Mattioli B, Scarpa M, Fiocchi C, Vecchi M, Pizarro TT: Epithelial-derived IL-33 and its receptor ST2 are dysregulated in ulcerative colitis and in experimental Th1/Th2 driven enteritis. Proc Natl Acad Sci USA 2010, 107:8017-8022. 
75. Beltran CJ, Nunez LE, Diaz-Jimenez D, Farfan N, Candia E, Heine C, Lopez F, Gonzalez MJ, Quera R, Hermoso MA: Characterization of the novel ST2/IL33 system in patients with inflammatory bowel disease. Inflamm Bowel Dis 2009.

76. Kobori A, Yagi Y, Imaeda H, Ban H, Bamba S, Tsujikawa T, Saito Y, Fujiyama $Y$, Andoh A: Interleukin-33 expression is specifically enhanced in inflamed mucosa of ulcerative colitis. J Gastroenterol 2010, 45:999-1007.

77. Seidelin JB, Bjerrum JT, Coskun M, Widjaya B, Vainer B, Nielsen OH: IL-33 is upregulated in colonocytes of ulcerative colitis. Immunol Lett 2010, 128:80-85

78. Ajdukovic J, Tonkic A, Salamunic I, Hozo I, Simunic M, Bonacin D: Interleukins IL-33 and IL-17/IL-17A in patients with ulcerative colitis. Hepatogastroenterology 2010, 57:1442-1444.

79. Rani R, Smulian AG, Greaves DR, Hogan SP, Herbert DR: TGF-beta limits IL33 production and promotes the resolution of colitis through regulation of macrophage function. Eur J Immunol 2011.

80. Hudson CA, Christophi GP, Gruber RC, Wilmore JR, Lawrence DA, Massa PT: Induction of IL-33 expression and activity in central nervous system glia. $J$ Leukoc Biol 2008, 84:631-643.

81. Yasuoka S, Kawanokuchi J, Parajuli B, Jin S, Doi Y, Noda M, Sonobe Y, Takeuchi H, Mizuno T, Suzumura A: Production and functions of IL-33 in the central nervous system. Brain Res 2011, 1385:8-17.

82. Chapuis J, Hot D, Hansmannel F, Kerdraon O, Ferreira S, Hubans C, Maurage CA, Huot L, Bensemain F, Laumet G, et al: Transcriptomic and genetic studies identify IL-33 as a candidate gene for Alzheimer's disease. Mol Psychiatry 2009, 14:1004-1016.

83. Yu JT, Song JH, Wang ND, Wu ZC, Zhang Q, Zhang N, Zhang W, Xuan SY, Tan L: Implication of IL-33 gene polymorphism in Chinese patients with Alzheimer's disease. Neurobiol Aging 2010.

84. Yoshida K, Arai T, Yokota T, Komatsu N, Miura Y, Yanagisawa K, Tetsuka T, Tominaga S: Studies on natural ST2 gene products in the human leukemic cell line UT-7 using monoclonal antihuman ST2 antibodies. Hybridoma 1995, 14:419-427.

85. Tsuchiya T, Ohshima K, Karube K, Yamaguchi T, Suefuji H, Hamasaki M Kawasaki C, Suzumiya J, Tomonaga M, Kikuchi M: Th1, Th2, and activated T-cell marker and clinical prognosis in peripheral T-cell lymphoma, unspecified: comparison with AILD, ALCL, lymphoblastic lymphoma, and ATLL. Blood 2004, 103:236-241.

86. Jovanovic I, Radosavljevic G, Mitrovic M, Lisnic Juranic V, McKenzie A, Arsenijevic N, Jonjic S, Lukic M: ST2 Deletion Enhances Innate and Acquired Immunity to Murine Mammary Carcinoma. Eur J Immunol 2011.

87. Choi YS, Choi HJ, Min JK, Pyun BJ, Maeng YS, Park H, Kim J, Kim YM, Kwon YG: Interleukin-33 induces angiogenesis and vascular permeability through ST2/TRAF6-mediated endothelial nitric oxide production. Blood 2009, 114:3117-3126.

88. Kuchler AM, Pollheimer J, Balogh J, Sponheim J, Manley L, Sorensen DR, De Angelis PM, Scott H, Haraldsen G: Nuclear interleukin-33 is generally expressed in resting endothelium but rapidly lost upon angiogenic or proinflammatory activation. Am J Pathol 2008, 173:1229-1242.

89. Bartunek J, Delrue L, Van Durme F, Muller O, Casselman F, De Wiest B, Croes R, Verstreken S, Goethals M, de Raedt $H$, et al: Nonmyocardial production of ST2 protein in human hypertrophy and failure is related to diastolic load. J Am Coll Cardiol 2008, 52:2166-2174.

90. Moussion C, Ortega N, Girard JP: The IL-1-like cytokine IL-33 is constitutively expressed in the nucleus of endothelial cells and epithelial cells in vivo: a novel 'alarmin'? PLOS One 2008, 3:e3331.

91. Wood IS, Wang B, Trayhurn P: IL-33, a recently identified interleukin-1 gene family member, is expressed in human adipocytes. Biochem Biophys Res Commun 2009, 384:105-109.

92. Sanada S, Hakuno D, Higgins L, Schreiter ER, McKenzie AN, Lee RT: IL-33 and ST2 comprise a critical biomechanically induced and cardioprotective signaling system. J Clin Invest 2007, 117:1538-1549.

93. Weinberg EO, Shimpo M, De Keulenaer GW, MacGillivray C, Tominaga S, Solomon SD, Rouleau JL, Lee RT: Expression and regulation of ST2, an interleukin-1 receptor family member, in cardiomyocytes and myocardial infarction. Circulation 2002, 106:2961-2966.

94. Kuhn E, Addona T, Keshishian H, Burgess M, Mani DR, Lee RT, Sabatine MS, Gerszten RE, Carr SA: Developing multiplexed assays for troponin I and interleukin-33 in plasma by peptide immunoaffinity enrichment and targeted mass spectrometry. Clin Chem 2009, 55:1108-1117.
95. Seki K, Sanada S, Kudinova AY, Steinhauser ML, Handa V, Gannon J, Lee RT: Interleukin-33 prevents apoptosis and improves survival after experimental myocardial infarction through ST2 signaling. Circ Heart Fail 2009, 2:684-691.

96. Yndestad A, Marshall AK, Hodgkinson JD, Thamel L, Sugden PH, Clerk A: Modulation of interleukin signalling and gene expression in cardiac myocytes by endothelin-1. Int J Biochem Cell Biol 2010, 42:263-272.

97. Hansson GK, Hermansson A: The immune system in atherosclerosis. Nat Immunol 2011, 12:204-212.

98. Davenport P, Tipping PG: The role of interleukin-4 and interleukin-12 in the progression of atherosclerosis in apolipoprotein E-deficient mice. Am J Pathol 2003, 163:1117-1125.

99. Gupta S, Pablo AM, Jiang X, Wang N, Tall AR, Schindler C: IFN-gamma potentiates atherosclerosis in ApoE knock-out mice. J Clin Invest 1997 99:2752-2761.

100. McLaren JE, Michael DR, Salter RC, Ashlin TG, Calder CJ, Miller AM, Liew FY, Ramji DP: IL-33 reduces macrophage foam cell formation. J Immunol 2010, 185:1222-1229.

101. Miller AM, Asquith DL, Hueber AJ, Anderson LA, Holmes WM, McKenzie AN, Xu D, Sattar N, McInnes IB, Liew FY: Interleukin-33 induces protective effects in adipose tissue inflammation during obesity in mice. Circ Res 2010, 107:650-658.

102. Moro K, Yamada T, Tanabe M, Takeuchi T, Ikawa T, Kawamoto H, Furusawa J, Ohtani M, Fujii H, Koyasu S: Innate production of $T(H) 2$ cytokines by adipose tissue-associated c-Kit(+)Sca-1(+) lymphoid cells. Nature 2010, 463:540-544.

103. Shimpo M, Morrow DA, Weinberg EO, Sabatine MS, Murphy SA, Antman EM, Lee RT: Serum levels of the interleukin-1 receptor family member ST2 predict mortality and clinical outcome in acute myocardial infarction. Circulation 2004, 109:2186-2190.

104. Sabatine MS, Morrow DA, Higgins LJ, MacGillivray C, Guo W, Bode C, Rifai N, Cannon CP, Gerszten RE, Lee RT: Complementary roles for biomarkers of biomechanical strain ST2 and N-terminal prohormone B-type natriuretic peptide in patients with ST-elevation myocardial infarction. Circulation 2008, 117:1936-1944.

105. Weir RA, Miller AM, Murphy GE, Clements S, Steedman T, Connell JM, McInnes IB, Dargie HJ, McMurray JJ: Serum soluble ST2: a potential novel mediator in left ventricular and infarct remodeling after acute myocardial infarction. J Am Coll Cardiol 2010, 55:243-250.

106. Brown AM, Wu AH, Clopton P, Robey JL, Hollander JE: ST2 in emergency department chest pain patients with potential acute coronary syndromes. Ann Emerg Med 2007, 50:153-158, 158 e151..

107. Weinberg EO, Shimpo M, Hurwitz S, Tominaga S, Rouleau JL, Lee RT: Identification of serum soluble ST2 receptor as a novel heart failure biomarker. Circulation 2003, 107:721-726.

108. Mueller T, Dieplinger B, Gegenhuber A, Poelz W, Pacher R, Haltmayer M: Increased plasma concentrations of soluble ST2 are predictive for 1-year mortality in patients with acute destabilized heart failure. Clin Chem 2008, 54:752-756.

109. Rehman SU, Mueller T, Januzzi JL Jr: Characteristics of the novel interleukin family biomarker ST2 in patients with acute heart failure. J Am Coll Cardiol 2008, 52:1458-1465.

110. Boisot S, Beede J, Isakson S, Chiu A, Clopton P, Januzzi J, Maisel AS, Fitzgerald RL: Serial sampling of ST2 predicts 90 -day mortality following destabilized heart failure. J Card Fail 2008, 14:732-738.

111. Pascual-Figal DA, Ordonez-Llanos J, Tornel PL, Vazquez R, Puig T, Valdes M, Cinca J, de Luna AB, Bayes-Genis A: Soluble ST2 for predicting sudden cardiac death in patients with chronic heart failure and left ventricular systolic dysfunction. J Am Coll Cardiol 2009, 54:2174-2179.

112. Porcel JM, Martinez-Alonso M, Cao G, Bielsa S, Sopena A, Esquerda A: Biomarkers of heart failure in pleural fluid. Chest 2009, 136:671-677.

113. Bayes-Genis A, Pascual-Figal D, Januzzi JL, Maisel A, Casas T, Valdes Chavarri M, Ordonez-Llanos J: Soluble ST2 Monitoring Provides Additional Risk Stratification for Outpatients With Decompensated Heart Failure. Rev Esp Cardiol 2010, 63:1171-1178.

114. Manzano-Fernandez S, Mueller T, Pascual-Figal D, Truong QA, Januzzi JL: Usefulness of soluble concentrations of interleukin family member ST2 as predictor of mortality in patients with acutely decompensated heart failure relative to left ventricular ejection fraction. Am J Cardiol 2011, 107:259-267. 
115. Ky B, French B, McCloskey K, Rame JE, McIntosh E, Shahi P, Dries DL, Tang WH, Wu AH, Fang JC, et al: High-Sensitivity ST2 for Prediction of Adverse Outcomes in Chronic Heart Failure. Circ Heart Fail 2011, 4:180-187.

116. Szerafin T, Brunner M, Horvath A, Szentgyorgyi L, Moser B, Boltz-Nitulescu G, Peterffy A, Hoetzenecker K, Steinlechner B, Wolner E, Ankersmit HJ: Soluble ST2 protein in cardiac surgery: a possible negative feedback loop to prevent uncontrolled inflammatory reactions. Clin Lab 2005, 51:657-663.

117. Szerafin T, Niederpold T, Mangold A, Hoetzenecker K, Hacker S, Roth G, Lichtenauer M, Dworschak M, Wolner E, Ankersmit HJ: Secretion of soluble ST2 - possible explanation for systemic immunosuppression after heart surgery. Thorac Cardiovasc Surg 2009, 57:25-29.

118. Daniels LB, Clopton P, lqbal N, Tran K, Maisel AS: Association of ST2 levels with cardiac structure and function and mortality in outpatients. Am Heart J 2010, 160:721-728.

119. Januzzi JL Jr, Peacock WF, Maisel AS, Chae CU, Jesse RL, Baggish AL, O'Donoghue M, Sakhuja R, Chen AA, van Kimmenade RR, et al: Measurement of the interleukin family member ST2 in patients with acute dyspnea: results from the PRIDE (Pro-Brain Natriuretic Peptide Investigation of Dyspnea in the Emergency Department) study. J Am Coll Cardiol 2007, 50:607-613.

120. Dieplinger B, Gegenhuber A, Kaar G, Poelz W, Haltmayer M, Mueller T: Prognostic value of established and novel biomarkers in patients with shortness of breath attending an emergency department. Clin Biochem 2010, 43:714-719.

121. Martinez-Rumayor A, Camargo CA, Green SM, Baggish AL, O'Donoghue M, Januzzi JL: Soluble ST2 plasma concentrations predict 1-year mortality in acutely dyspneic emergency department patients with pulmonary disease. Am J Clin Pathol 2008, 130:578-584.

122. Rehman SU, Martinez-Rumayor A, Mueller T, Januzzi JL Jr: Independent and incremental prognostic value of multimarker testing in acute dyspnea: results from the ProBNP Investigation of Dyspnea in the Emergency Department (PRIDE) study. Clin Chim Acta 2008, 392:41-45.

123. Shah RV, Chen-Tournoux AA, Picard MH, van Kimmenade RR, Januzzi JL: Serum levels of the interleukin-1 receptor family member ST2, cardiac structure and function, and long-term mortality in patients with acute dyspnea. Circ Heart Fail 2009, 2:311-319.

doi:10.1186/1476-9255-8-22

Cite this article as: Miller: Role of IL-33 in inflammation and disease. Journal of Inflammation 2011 8:22.

\section{Submit your next manuscript to BioMed Central and take full advantage of:}

- Convenient online submission

- Thorough peer review

- No space constraints or color figure charges

- Immediate publication on acceptance

- Inclusion in PubMed, CAS, Scopus and Google Scholar

- Research which is freely available for redistribution

Submit your manuscript at www.biomedcentral.com/submit 